\title{
Relationship between the acid-induced cough response and airway responsiveness and obstruction in children with asthma
}

\author{
Toshio Shimizu, Hiroyuki Mochizuki, Kenich Tokuyama, Akihiro Morikawa
}

\begin{abstract}
Background - In children with asthma little is known about the direct effect of the bronchoconstrictor and bronchodilator response on the cough threshold, or the relationship between bronchial responsiveness and the cough threshold. A study was undertaken to determine the effect of histamine-induced bronchoconstriction and salbutamol-induced bronchodilatation on the cough threshold in response to inhaled acetic acid, and to examine the relationship between the acetic acid cough threshold and bronchial hyperresponsiveness to histamine in children with asthma.
\end{abstract}

Methods - Nineteen children with asthma ( 16 boys) of mean (SE) age $10.6(0.6)$ years were enrolled in the study. On day 1 each underwent a histamine inhalation challenge to determine the provocative concentration causing $a$ fall in forced expiratory volume in one second $\left(F E V_{1}\right)$ of more than $20 \%\left(\mathrm{PC}_{20}\right)$ as an index of individual bronchial hyperresponsiveness. On day 2 the acetic acid cough threshold was determined before and just after the inhalation of the $\mathbf{P C}_{20}$ concentration of histamine, and then salbutamol $\left(1 \mathrm{mg} / \mathrm{m}^{2}\right)$ was inhaled to relieve the bronchoconstriction. Ten of the 19 patients (eight boys) of mean age $12 \cdot 2(0 \cdot 7)$ years also tried acetic acid inhalation challenge just after salbutamol inhalation.

Results - There was no relationship between the bronchial responsiveness to histamine and acetic acid cough threshold in these patients. The acetic acid cough threshold after histamine inhalation was similar to that before histamine, although $\mathrm{FEV}_{1}$ decreased after histamine. In the $\mathbf{1 0}$ patients who also tried acetic acid inhalation challenge after salbutamol the cough threshold did not change.

Conclusions - These findings suggest that acid-induced cough sensitivity and bronchomotor tone are independently regulated in children with asthma.

(Thorax 1996;51:284-287)

Keywords: bronchial responsiveness, childhood asthma, cough threshold.

In patients with asthma, cough and bronchoconstriction often occur simultaneously and may be closely related. However, accumulating data indicate that cough and bronchocon- striction are separate airway reflexes. We have reported that inhaled acid can elicit cough without bronchoconstriction in asthmatic children. ${ }^{1}$ The absence of permeant anion - for example, chloride - in an isosmolar solution causes cough but not bronchoconstriction. ${ }^{2}$ Inhalation of local anaesthetics inhibits cough but not bronchoconstriction, while sodium cromoglycate inhibits bronchoconstriction but not cough induced by distilled water. ${ }^{3}$ These observations suggest that the mechanisms of cough and bronchoconstriction are related but can be independently triggered. Fujimura et al recently reported that in normal adult subjects methacholine-induced bronchoconstriction and procaterol-induced bronchodilation did not change the cough threshold induced by inhaled capsaicin and tartaric acid. ${ }^{4}$ However, less is known about the direct effect of the bronchoconstrictor and bronchodilator response on the cough threshold in children with asthma.

In the present study we examined whether changes in bronchomotor tone influence the cough threshold in children with asthma. We evaluated the effect of histamine-induced bronchoconstriction and salbutamol-induced bronchodilation on the cough threshold in response to inhaled acetic acid, and examined the relationship between the acetic acid cough threshold and bronchial hyperresponsiveness to histamine in children with asthma.

Methods

SUBJECTS

Nineteen children with atopic asthma ( 16 boys) of mean (SE) age 10.6 (0.6) years were enrolled in the study. The clinical diagnosis of bronchial asthma was based on a characteristic history of recurrent attacks of dyspnoea with perceptible wheezing. The diagnosis was made after more than one year of follow up. All subjects reacted to allergens in the skin prick test and/or in the radioallergosorbent test (RAST) (development of a wheal $5 \mathrm{~mm}$ or larger in a prick test and more than 0.70 PRU in the RAST).

All the patients had been free from upper respiratory tract infections for at least four weeks. They had no asthma-related symptoms at the time of the study. All medications were stopped at least 12 hours before each challenge test.

Informed consent for the study was obtained from the patients and their parents before the examination. The study was approved by the ethics committee of the hospital.

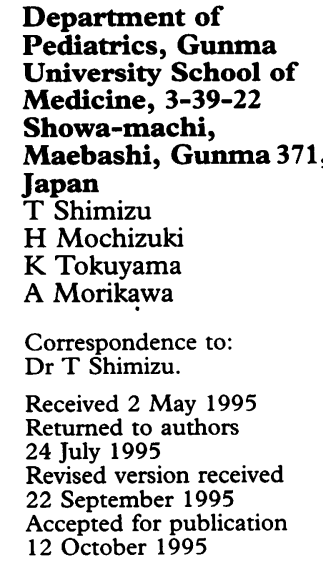


HISTAMINE INHALATION CHALLENGE

Histamine inhalation challenge was performed according to the method of Townley et af with a slight modification. Spirometric tests were performed in each patient. The aerosols were generated by the DeVilbiss model 646 nebuliser (DeVilbiss, Somerset, Pennsylvania, USA) with a constant airflow of $5 \mathrm{l} / \mathrm{min}$. A noseclip was worn and aerosol was inhaled by tidal breathing for two minutes. An aerosol of normal saline solution was inhaled first, followed by twofold increasing concentrations of histamine dihydrochloride (Sigma Chemical Co, St Louis, USA) solutions (from 0.02 to $10 \mathrm{mg} / \mathrm{ml}$ ). The forced expiratory volume in one second $\left(\mathrm{FEV}_{1}\right)$ was measured just after each inhalation. Inhalations were carried out until there was a fall in $\mathrm{FEV}_{1}$ of more than $20 \%$ compared with the inhalation of control saline, or until the highest concentration was reached. The concentration of histamine leading to a fall in $\mathrm{FEV}_{1}$ of more than $20 \%\left(\mathrm{PC}_{20}\right)$ was considered to be the threshold of the hyperresponsiveness to histamine.

\section{ACETIC ACID INHALATION CHALLENGE}

The procedure of acetic acid inhalation challenge has been described previously ${ }^{67}$ and was similar to that of Mitsuhashi et al ${ }^{1}$ which has good reproducibility. Briefly, acetic acid solution was prepared on the same day and diluted twofold with $0.9 \%$ saline solution (from 0.04 to $20 \%$, pH 3.13-1.62, osmolarity 292-1113 $\mathrm{mOsm} / \mathrm{kg}$ ), and administered via a DeVilbiss model 646 nebuliser with a constant airflow of $5 \mathrm{l} / \mathrm{min}$. The $\mathrm{FEV}_{1}$ was measured just before and after each inhalation challenge. After local anaesthesia was administered to the nasopharynx by procaine swabbing the subjects wore a noseclip and inhaled the aerosol by tidal breathing for 10 seconds. An aerosol of normal saline solution was inhaled first, followed by twofold increasing concentrations of acetic acid (from 0.04 to $20 \%$ ) until there was a first cough, recognised by more than two independent observers, or until the highest concentration was reached. It was agreed that the percentage of the acetic acid concentration inducing the first cough would be considered to be the threshold of hyperresponsiveness of cough receptors.

EXPERIMENTAL PROTOCOL

On day 1 each patient underwent histamine inhalation challenge to determine the $\mathrm{PC}_{20}$ as the index of the individual bronchial hyperresponsiveness. On day 2 (one week from day 1 ) the acetic acid cough threshold was determined before and just after the inhalation of the $\mathrm{PC}_{20}$ concentration of histamine for two minutes. Spirometric tests were performed before and after inhalation of acetic acid and histamine. When all the measurements were completed, a $\beta_{2}$ adrenergic agonist, salbutamol $\left(1 \mathrm{mg} / \mathrm{m}^{2}\right)$, was inhaled to relieve the bronchoconstriction.

Ten of the 19 patients (eight boys) of mean age $12 \cdot 2(0 \cdot 7)$ years tried a further acetic acid inhalation challenge just after the salbutamol

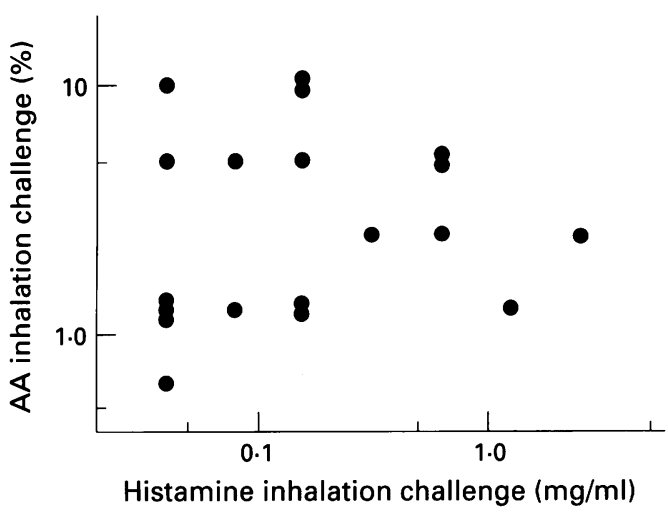

Figure 1 Relationship between cough threshold to inhaled acetic acid $(A A)$ and non-specific bronchial responsiveness to histamine $\left(P C_{20}\right)$ in 19 children with asthma. No significant relationship was observed between these values.

inhalation and spirometric tests were performed before and after the inhalation of salbutamol.

\section{STATISTICAL ANALYSIS}

Wilcoxon's matched pairs signed rank test was used to compare spirometric values and the acetic acid cough threshold, and Friedman's two way analysis of variance was used to compare multiple groups. For correlations between variables Spearman's rank analysis was used. A probability of less than 0.05 was considered significant.

\section{Results}

\section{RELATIONSHIP BETWEEN COUGH THRESHOLD}

AND BRONCHIAL HYPERRESPONSIVENESS

Figure 1 shows the relationship between the cough threshold (values in the first acetic acid inhalation challenge before histamine) and bronchial hyperresponsiveness to histamine in all 19 children with asthma. There was no relationship between the cough threshold value to inhaled acetic acid and the $\mathrm{PC}_{20}$ value to histamine in these patients $(r=0 \cdot 184, \mathrm{NS})$.

\section{EFFECT OF BRONCHOCONSTRICTION ON COUGH} THRESHOLD

The mean $\mathrm{FEV}_{1}$ before and after the first acetic acid inhalation challenge (before histamine) was $1.67(0 \cdot 11)$ and $1.69(0 \cdot 11) 1$, respectively. There was no significant change between these values. After inhalation of histamine the $\mathrm{FEV}_{1}$ decreased significantly to $1.20(0.09) 1$ $(\mathrm{p}<0.01)$, but no significant change was observed between the values of acetic acid cough threshold before and after histamine (3.78 $(0.71) \%$ and $3.91(0.69) \%$, respectively, fig 2$)$.

EFFECT OF BRONCHODILATION ON COUGH THRESHOLD

The $\mathrm{FEV}_{1}$ before and after inhalation of histamine and after salbutamol inhalation in the 10 patients who tried a further acetic acid inhalation challenge after salbutamol decreased after histamine and significantly increased after salbutamol $(p<0.01)$. There was, however, no 


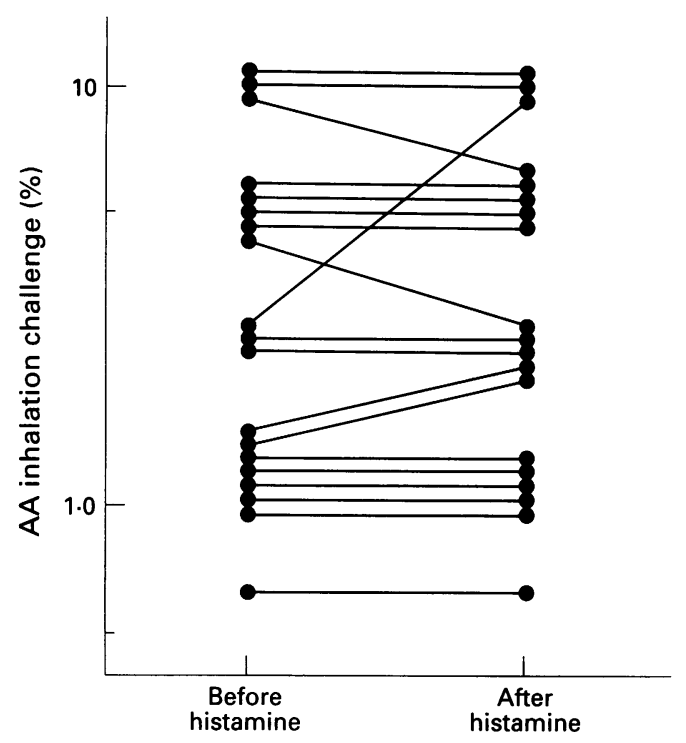

Figure 2 Threshold of cough response to inhaled acetic acid $(A A)$ before and after histamine-induced bronchoconstriction in 19 children with asthma. No significant change in the acetic acid cough threshold was observed.

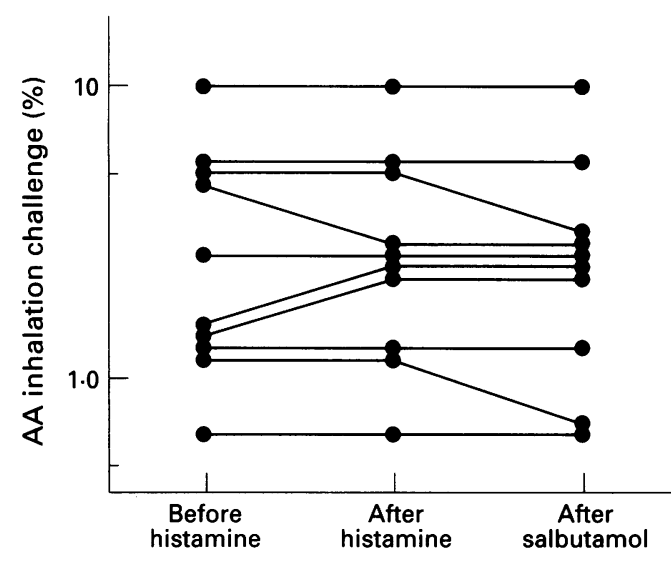

Figure 3 Threshold of cough response to inhaled acetic acid $(A A)$ before histamine, after histamine, and after salbutamol inhalation in 10 children with asthma. No significant change was observed between the acetic acid cough threshold values.

significant change between the values of the acetic acid cough threshold after histamine and that after salbutamol $(3.31(0.83) \%$ and $3.00(0.83) \%$, respectively). Furthermore, no change was observed between the acetic acid cough threshold values and those before histamine inhalation (fig 3).

\section{Discussion}

In this study we have shown that the acetic acid cough threshold is independent of bronchial hyperresponsiveness to histamine, and that the bronchoconstrictor and bronchodilator responses do not change the acetic acid cough threshold in children with asthma.

We initially tried to perform this study in a double blind placebo controlled fashion but the patients were able to distinguish active (histamine) from placebo (saline) because they felt dyspnoeic after the histamine inhalation. The physician attending the study also noted wheeze in the patients after inhalation of histamine.

In asthmatic patients wheezing, which is mainly caused by bronchoconstriction, and cough are common symptoms. ${ }^{8}$ However, the mechanism of hypersensitivity to bronchoconstriction and cough in asthmatic subjects still remains unclear. Accumulating data have suggested that the two airway reflexes of cough and bronchoconstriction have separate afferent neural pathways and may have a different sensitivity to inhibitory drugs. ${ }^{39-11}$ Eschenbacher et al reported that hyperosmolarity was the stimulus that caused both cough and bronchoconstriction, with a low ion concentration inducing cough but not bronchoconstriction. ${ }^{2}$ This suggests that bronchoconstriction and cough are produced by stimulation of different populations of afferent nerve endings - that is, irritant receptors and cough receptors.

Cough is a reflex response of the respiratory tract and is produced by inflammatory, mechanical, chemical, and thermal stimulation of the cough receptors, ${ }^{1213}$ which are believed to be the fine sensory nerve endings of the trigeminal, glossopharyngeal, superior laryngeal, and vagal nerves. Although it is not yet certain why low concentration acid inhalation can induce cough in asthmatic patients, ionic and/or osmolar change in airway luminal fluid may stimulate cough receptors in the mucosa and submucosa directly or indirectly. ${ }^{214}$

With regard to the relationship between the cough threshold and the degree of bronchial hyperresponsiveness, there have been only a few reports indicating that they are independent of each other in adult asthmatic and normal subjects. ${ }^{1516}$ We have recently reported that the acetic acid cough threshold does not correlate with the degree of bronchial hyperresponsiveness to histamine in children with asthma. ${ }^{17}$ In the present study we have reconfirmed this result with a different population and the above findings would indicate that cough sensitivity does not directly correlate with bronchial responsiveness.

With the same patients we examined whether or not the bronchoconstrictor and bronchodilator responses influence the acetic acid cough threshold. Although the direct effect of histamine on cough receptor sensitivity has not been well known, we could find no change in the acetic acid cough threshold after inhalation of a sufficient dose of histamine to cause at least a $20 \%$ fall in $\mathrm{FEV}_{1}$. Although our study was not a controlled trial, the possibility that the unchanged acetic acid cough threshold after histamine is due to tachyphylaxis ${ }^{18}$ would be unlikely because, as shown in fig 3 , the acetic acid cough threshold did not change after salbutamol. This suggests that the cough response is unrelated to the degree of bronchoconstriction. This is consistent with the clinical observation that cough in asthmatic patients is not related to the degree of airways obstruction.

With regard to the effect of inhaled salbutamol, we could find no efficacy in modifying the acetic acid cough threshold in a dose which was sufficient to reduce bronchomotor tone. There have been conflicting reports about the 
antitussive potency of inhaled $\beta_{2}$ agonists. Cough induced by distilled water and prostaglandin $F_{2 x}$ was reduced by inhalation of fenoterol in both asthmatic and normal subjects, ${ }^{19-21}$ acid-induced cough was inhibited by inhaled salbutamol in asthmatic adults, ${ }^{22}$ while inhaled salbutamol and procaterol had no effect on acid-induced and capsaicin-induced cough in normal subjects. ${ }^{42122}$ Our results confirm the lack of effect of inhaled salbutamol on the acetic acid-induced cough threshold in children with asthma. Judging from these observations, if an inhaled $\beta_{2}$ agonist has any antitussive activities, it is probably due to its indirect action to change conditions in the vicinity of the cough receptors. ${ }^{4}$ The same also applies to the protective mechanism of inhaled frusemide against various stimuli. ${ }^{23-26}$ We have reported that inhaled frusemide can attenuate the acetic acid-induced cough threshold in children with asthma. ${ }^{717}$

In conclusion, we have shown that the acetic acid-induced cough threshold is independent of non-specific bronchial hyperresponsiveness, and that the bronchoconstrictor and bronchodilator response does not change the acetic acid-induced cough threshold. These results indicate that acid-induced cough and bronchomotor tone are independently regulated even in children with asthma.

1 Mitsuhashi M, Mochizuki H, Tokuyama K, Morikawa A, Kuroume T. Hyperresponsiveness of cough receptors in patients with bronchial asthma. Pediatrics 1985;75:855-8.
2 Eschenbacher WL, Boushey HA, Sheppard D. Alteration in osmolarity of inhaled aerosols cause bronchoconstriction and cough, but absence of a permeant anion causes cough alone. Am Rev Respir Dis 1984;129:211-5.

3 Sheppard D, Rizk NW, Boushey HA, Bethel RA. Mechanism of cough and bronchoconstriction induced by distilled water aerosol. Am Rev Respir Dis 1983;127:691-4.

4 Fujimura M, Sakamoto S, Kamio Y, Matsuda T. Effect of methacholine induced bronchoconstriction and procaterol induced bronchodilation on cough receptor sensitivity to inhaled capsaicin and tartaric acid. Thorax 1992;47:441-5.

5 Townley RJ, Hopp RJ. Inhalation methods for the study of airway responsiveness. F Allergy Clin Immunol 1987;80 111-24.

6 Yokoyama T, Mochizuki H, Shigeta M, Morikawa A, Arakawa $\mathrm{H}$, Tateno $\mathrm{K}$, et al. Cough provocation test in asthmatic children. Fapan $\mathcal{F}$ Allergol 1990;39:1576-80.
7 Mochizuki H, Shimizu T, Morikawa A, Kuroume T. Inhaled diuretics attenuate acid-induced cough in children with asthma. Chest 1995;107:413-7.

$8 \mathrm{McF}$ adden ER Jr. Exertional dyspnea and cough as preludes to acute attacks of bronchial asthma. $N$ Engl $f$ Med 1975; 292:555-9.

9 Karlsson J-A, Sant'Ambrogio G, Widdicombe J. Afferent neural pathways in cough and reflex bronchoconstriction. f Appl Physiol 1988;65:1007-23.

10 Godden DJ, Barland C, Lowry R, Higenbottam TW. Chemical specificity of coughing in man. Clin Sci 1986;70. 301-6.

11 Choudry NB, Fuller RW, Anderson N, Karlsson J-A. Separation of cough and reflex bronchoconstriction by inhaled local anesthetics. Eur Respir 7 1990;3:579-83.

12 Coleridge JCG, Coleridge HM. Afferent vagal C fibre innervation of lungs and airways and its functional signervation of lungs and airways and its functional sig-
nificance. Rev Physiol Biochem Pharmacol 1984;99:1-110.

13 Sant'Ambrogio G. Afferent pathways for the cough reflex. Bull Eur Physiopathol Respir 1987;23(Suppl 10):19-24s.

14 Fine JM, Gordon T, Thompson JE, Sheppard D. The role of titratable acidity in acid aerosol-induced bronchoconstriction. Am Rev Respir Dis 1987;135:826-30.

15 Auffarth B, De Monchy JGR, Van der Mark ThW, Postma DS, Koeter GH. Citric acid cough threshold and airway responsiveness in asthmatic patients and smokers with responsiveness in asthmatic patients and smokers

16 Fujimura M, Sakamoto S, Kamio Y, Matsuda T. Cough receptor sensitivity and bronchial responsiveness in norma and asthmatic subjects. Eur Respir f 1992;5:291-5.

17 Mochizuki H, Shimizu T, Maeda S, Tokuyama K, Morikawa A, Kuroume T. Relationship between ultrasonically nebulized distilled water-induced bronchoconstriction and acid-induced cough in asthmatic children. $\mathcal{F}$ Allergy Clin Immunol 1995;96:193-9.

18 Pounsford JC, Saunders KB. Diurnal variation and adaptation of the cough response to citric acid in normal aptation of the cough response to
subjects. Thorax 1985;40:657-61.

19 Lowry R, Higenbottam T, Johnson T, Godden D. Inhibition of artificially induced cough in man by bronchodilators. Br f Clin Pharmacol 1987;24:503-10.

20 Lowry R, Wood A, Johnson T, Higenbottam T. Antitussive properties of inhaled bronchodilators of induced cough Chest 1988;93:1186-9.

21 Nichol G, Nix A, Barnes PJ, Chung KF. Prostaglandin $F_{2 x}$ enhancement of capsaicin induced cough in man: modulation by $\beta_{2}$ adrenergic and anticholinergic drugs. Thorax 1990;45:694-8.

22 Pounsford JC, Birch MJ, Saunders KB. Effect of bronchodilators on the cough response to inhaled citric acid in normal and asthmatic subjects. Thorax 1985;40:662-7.

23 Bianco S, Vaghi A, Robuschi M, Pasargiklian M. Prevention of exercise-induced bronchoconstriction by inhaled furosemide. Lancet 1988;ii:252-5.

24 Bianco S, Pieroni MG, Refini RM, Rattoli L, Sestini P. Protective effect of inhaled furosemide on allergen-induced early and late asthmatic reactions. $N$ Engl $f$ Med 1989;321:1069-73.

25 Ventresca PG, Nichol GM, Barnes PJ, Chung KF. Inhaled furosemide inhibits cough induced by low chloride content solutions but not by capsaicin. Am Rev Respir Dis 1990 142:143-6.

26 Shimizu T, Mochizuki H, Morikawa A, Kuroume T. Inhaled furosemide prevents ultrasonically nebulized water bronchoconstriction in children with both atopic and nonatopic asthma. Chest 1993;104:1723-6. 